\title{
RELATIONSHIP BETWEEN THE ALLOY FREQUENCY OF THE T102C POLYMORPHISM OF THE 5HT2A GENE WITH ANTHROPOMETRIC AND CARDIOMETABOLIC MEASURES
}

\author{
Mallmanna BLK \\ Scholarship holder of Laboratory of Molecular Biology - Department of Life Sciences \\ - Universidade do Oeste de Santa Catarina of São Miguel do Oeste; Pharmaceutical; \\ bmallmann@gmail.com; https://orcid.org/0000-0002-8123-8568
}

\section{Tonini CRA}

Scholarship holder of Laboratory of Molecular Biology - Department of Life Sciences - Universidade do Oeste de Santa Catarina of São Miguel do Oeste; Pharmaceutical; clauciatonini@gmail.com; https://orcid.org/0000-0002-8828-115

\section{Vidigal TMA}

Master in Biomecine and Biomedical for Universidade Paranaense; Teacher of Laboratory of Molecular Biology - Department of Life Sciences - Universidade do Oeste de Santa Catarina of São Miguel do Oeste; tiagovididal@gmail.com; https://orcid.org/00000003-0601-8482

\section{Chielle EO}

Doctor and Master of Pharmaceutical Sciences for Universidade Federal de Santa Maria; Teacher of Laboratory of Clinical Biochemistry - Department of Life Sciences - Universidade do Oeste de Santa Catarina of São Miguel do Oeste; Rua Oiapoc, 211, Agostini, 89900-000, São Miguel do Oeste, Santa Catarina, Brasil; eduardochielle@ yahoo.com.br; https://orcid.org/0000-0003-3566-1258

\begin{abstract}
Obesity is a disease characterized by excessive body fat. Among the neurobiological factors associated with obesity, the serotonergic system stands out. The neurotransmitter of these circuits is serotonin (5-HT). Decreased levels of 5-HT have been linked to increased desire to ingest sweets and carbohydrates. This study aims to verify the relationship of the $5 \mathrm{HT} 2 \mathrm{~A}$ T102C gene polymorphism with obesity and anthropometric parameters. Blood samples and anthropometric data were collected from 150 volunteers, divided between the control and obese groups. The results showed that for individuals with diastolic pressure ( $p=0.3681)$, Estimated Mean Glycemia (GMe) $(p=0.0228)$ and Homeostatic Model Assessment (HOMA-IR-IR) $(p=0.001)$ all altered, a higher frequency of $C$ alleles was observed. For normal GMe ( $p=0.0270)$, a higher frequency of the T allele was observed. There was no difference for the allele distribution between the normal and altered groups for the parameters of Triglycerides, HDL cholesterol, total cholesterol,
\end{abstract}


glycated hemoglobin and Insulin. The distribution of the alleles between the groups, normal diastolic pressure $(p=0.3681)$ and HOMA-IR $(p=0.9203)$ groups presented no difference. From the genotypic analyzes of the T102C polymorphism of the $5 \mathrm{HT} 2 \mathrm{~A}$ gene, it was possible to demonstrate a relationship between the presence of the $C$ allele with biochemical and anthropometric markers related to obesity and hypertension.

Keywords: Obesity. 5HT2A. Polymorphism. Cholesterol. BMI.

\section{INTRODUCTION}

Obesity is a disease characterized by excessive body fat that causes damage of varying degrees and undesirable consequences to the health of individuals. The disease has been emerging in recent years in countries with high or low economic development and presents a risk similar to underweight, malnutrition and infectious diseases to public health. ${ }^{1}$ Currently, obesity is among the main causes of other secondary diseases such as type 2 diabetes, cardiovascular disease, high cholesterol, infertility and even some types of cancer, creating a high cost of health care for the treatment of such diseases. ${ }^{2}$

The etiology of obesity is multifactorial and therefore complex, involving the interaction of environmental, behavioral, genetic, endocrine, metabolic and neural factors. Bechtholt, Smith, Gaughan and Lucki ${ }^{3}$ suggest that the study of neural genes with psychophysiological functions has gained attention in the field of obesity, because they are associated with appetite control and satiety, thus interconnecting them with being overweight.

Among the neurobiological factors associated with obesity, the serotonergic system stands out. Anatomical, pharmacological and genetic evidences suggest a strong correlation between these circuits and a series of psychosocial actions and regulation of physiological processes of the central nervous system, such as the control of energy levels, glucose homeostasis and satiety. ${ }^{4}$ The neurotransmitter of these circuits is serotonin $(5-\mathrm{HT})$, chemically this molecule is characterized as an indolamine, a product of the hydroxylation and carboxylation of the amino acid tryptophan, produced in the nuclei of the brain stem raphe. ${ }^{5}$

Several studies suggest that 5-HT plays an important role in satiety. Changes in 5-HT levels (low levels or problems with receptor signaling) have been linked to an increased desire to eat sweets and carbohydrates. With normal amounts of $5-\mathrm{HT}$, the individual reaches satiety more easily and gets more control over the intake of sugars. Adequate levels of this 
neurotransmitter in the brain depend on the dietary intake of tryptophan (precursor amino acid serotonin) and carbohydrates. ${ }^{6,7}$ Drugs that inhibit 5-HT reuptake are increasingly used for weight loss, being used in the treatment of obesity, since they intensify the satiety power in the components of post-ingestion and post-absorption of food. ${ }^{5,8}$

Considering the metabolic role of serotonin, researchers studied the genetic and molecular mechanisms of this system. According to Yuan, Yamada K, IshiyamaShigemoto, Koyama and Nonaka, ${ }^{9}$ at least seven types of serotonin receptors (5HT-R) were characterized and at least two polymorphisms were recognized for types 1, 2 and 5 .

In the region 102, is located the polymorphism $\mathrm{T} 102 \mathrm{C}$, in which a thymine $(\mathrm{T})$ or a cytosine (C) can be positioned and thus expressing three possibilities of combinations for the 5-HT2A gene (genotypes TT, CT or CC). Both the TCT or TCC sequences in that region, encode the serine, not altering the amino acid sequences of the receptor. However, the $\mathrm{T}$ and $\mathrm{C}$ alleles determine a different gene expression, since Polesskaya and Sokolov ${ }^{10}$ demonstrated that the expression of the $C$ allele is $20 \%$ lower in comparison to the $T$ allele, generating lower uptake of serotonin.

Further research to more accurately determine the role of the 5-HT 2A receptor in obesity in order to identify regulatory pathways and serotonin influences on appetite may be useful in the development of new drugs for the treatment of obesity disease." In view of the above, this study aims to verify the relationship of the $5 \mathrm{HT} 2 \mathrm{~A} \mathrm{T1O2C}$ gene polymorphism with obesity and anthropometric parameters.

\section{MATERIAL AND METHODS}

\subsection{DELIMITATION OF THE STUDY}

This was a descriptive, cross-sectional study aimed at obtaining a clinical, epidemiological, laboratory and molecular evaluation, in order to investigate the prevalence of $5 \mathrm{HT} 2 \mathrm{~A}$ gene polymorphism in samples of obese adults from the far west of Santa Catarina. We evaluated 150 individuals of both sexes and over 18 years of age, separated between the test and control groups. 
The subjects in the test group underwent an interview, which addressed issues related to eating habits, frequency of physical activities and use of drugs. The results obtained in the biochemical and anthropometric analyzes were divided between values inside and outside the reference value.

The patients were recruited from basic health units. The protocol of the study was approved by the Ethics Committee of the University of West Santa Catarina (Unoesc $\left.n^{\circ} 219.091\right)$ and all participants provided written informed consent. Obesity status was classified according to the criteria established by the World Health Organization. ${ }^{12}$ The participants were non-smokers and were not taking any medications. We selected all obese, overweight and non-obese subjects without previous diseases such as diabetes mellitus, coronary, stroke, neoplasms, other diseases, or dysfunctions that could influence the obese state and genotype distribution.

\subsection{COLLECTION AND STORAGE OF MATERIAL}

For the analyzes, $5 \mathrm{~mL}$ of blood were collected with syringe, later stored in tubes containing anticoagulant (EDTA) and dry tubes without anticoagulant containing gel separator. They were duly identified and taken to the Molecular Biology Laboratory of Unoesc - São Miguel do Oeste Campus for further analysis. Anthropometric data of 150 volunteers were also registered.

\subsection{BIOCHEMICAL ANALYSIS}

The annalises of glucose, cholesterol, triglycerides, and HDL-cholesterol levels were performed at Cobas Mira (Roche Diagnostics, Basel, Switzerland) clinical chemistry analyzer using commecially available assay kits reagents by Labtest Diagnostics ${ }^{\circledR}$, Lagoa Santa, Brazil) according to manufacturer, all analyses were performed at Cobas Mira (Roche Diagnostics, Basel, Switzerland) clinical chemistry analyzer using standard methods. LDLcholesterol levels were calculated using the Friedewald formula. ${ }^{13}$

Insulin was determined by electrochemiluminescence immunoassay (Biomedix diagnóstica, São Paulo, Brazil) using an Elecsys 2010 analyzer (Roche diagnostics ${ }^{\circledR}$, Basel, 
Switzerland). Insulin resistance index was calculated by homeostasis model assessment of insulin resistance (HOMA-IR) as: (fasting insulin $\mathrm{mlU} / \mathrm{L}) \times($ fasting glucose $\mathrm{mg} / \mathrm{dL}$ )/22.5 . Glycated hemoglobin $\left(\mathrm{HbA}_{1 \mathrm{c}}\right)$ was measured by high-performance liquid chromatography (HPLC) (Tosoh 2.2 Plus A1C, Tosoh Corporation, Tokyo, Japan) method, certified by the National Glycohemoglobin Standadization Program and is standardized by the International Federation of Clinical Chemistry. GME was estimated using the following formula: 28.7 x A1C - 46.7 as recommended by the American Diabetes Association (ADA)

\subsection{MOLECULAR ANALYSIS}

The technique used for the genetic analyzes was the Polymerase Chain Reaction (PCR), performed through the Phusion Blood Direct PCR Kit (Thermo Scientific ${ }^{\circledast}$, Massachussetts, USA). The reaction of PCR from the kit was run in a final volume of 20 $\mu \mathrm{L}$, using buffer containing all reagents for extraction, DNA polymerase, specific primers, sterile water and sample DNA.

The amplifications were performed through a Thermocycler apparatus (Biocycler ${ }^{\circledR}$, China), which subjected the samples to cycles with denaturation temperatures, annealing of the primers and extension of the DNA strand of the region of interest. The reaction products were digested by the restriction enzyme Mspl (Thermo Scientific ${ }^{\circledR}$, Massachussetts, USA), for the $5 \mathrm{HT} 2 \mathrm{~A}$ gene and then separated by agarose gel electrophoresis for further visualization with ultraviolet light. Amplification product sizes were compared to specific standards. In the T102C polymorphism of the $5 \mathrm{HT} 2 \mathrm{~A}$ gene, the $\mathrm{T}$ allele presented blunt restriction enzyme with a band at 342 base pairs (bp) and the C allele had two 216bp and 126bp DNA bands.

\subsection{ANTHROPOMETRIC AND PRESSORIC ANALYSIS}

The techniques used to obtain the anthropometric measurements were performed according to Anthropometric Standardization Reference Manual. Three measures were taken, and the average between them was considered valid. The height was measured in centimeters $(\mathrm{cm})$, in a wall stadiometer (Professional ES2020 Sanny ${ }^{\circledR}$, Brazil). The weight was verified in kilograms $(\mathrm{kg})$ in a scale (model Glass 180, platform type, G-tech, Brazil). 
The Body Mass Index (BMI) was expressed in $\mathrm{kg} / \mathrm{m}^{2}$, according to the Brazilian Society of Obesity. Systolic Arterial Pressures (PAS) and Diastolic Blood Pressures (PAD) were measured in the seated position, after 10 minutes of rest. The right arm was supported at the cardiac level and used a pressure device with an auscultatory sphygmomanomet (BectonDicknson, $\mathrm{BD}^{\circledR}$, Franklin Lakes, USA). All measurements were taken on the left side of the body. ${ }^{14,15}$ During the anthropometric measurements, all participants were barefoot and clothed appropriately.

\subsection{STATISTICAL ANALYSIS}

The allelic and genotype frequencies of the population were calculated, and individuals with kinship were excluded to avoid frequency deviation. The data were evaluated to know if the frequencies are in Hardy-Weinberg equilibrium. The distribution of allele and genotype frequencies were submitted to the Chi-square test, values of p 0.05 were considered significant. Data analysis was performed using SPSS software (version 19.0).

\section{RESULTS}

The absolute values of serum and anthropometric determinations are given in Table 1. Differences between observed and expected genotype frequencies were observed for individuals with normal triglyceride levels $(p=0.0119)$, normal BMI $(0.0037)$ and normal glycated hemoglobin $(p=0.035)$. The studied population is not found in Hardy-Weinberg equilibrium ( $p<0.05)$. For individuals with PAD ( $p=0.3681)$, GMe $(p=0.0228)$ and HOMAIR $(p=0.0010)$ all altered, a higher frequency of $C$ alleles was observed, whereas for individuals with normal GMe $(p=0.0270)$ a greater frequency of the T allele was observed. There was no difference regarding the distribution of the alleles between the normal $(N)$ and altered (A) groups for the triglyceride ( $N, p=1.0000$ ); $A, p=0.9203$ ), HDL cholesterol $(N, p=0.3681 ; A, p=0.9203)$, total cholesterol $(N, p=0.9203, A, p=0.9203)$, glycated hemoglobin $p=0.7642)$ and Insulin $(N, p=0.4839 ; A, p=0.1936)$ parameters. The distribution of the alleles between the groups, normal diastolic $(p=0.3681)$ and HOMA-IR $(p=0.9203$ ) groups did not reach statistical difference (Table 2 ). 
Table 1 - Biochemical and anthropometric profiles of study participants

\begin{tabular}{|c|c|c|}
\hline Parameters & Results & $p$ value \\
\hline Triglycerides (mg/dL) - Normal & $89.75( \pm 29.12)$ & $<0.0001$ \\
\hline Triglycerides (mg/dL) - Altered & $239( \pm 92.26)$ & \\
\hline HDL-cholesterol (mg/dL) - Normal & $51.50( \pm 7.55)$ & $<0.0001$ \\
\hline HDL-cholesterol (mg/dL) - Altered & $31.89( \pm 5.21)$ & \\
\hline LDL-cholesterol (mg/dL) - Normal & $97.03( \pm 20.73)$ & $<0.0001$ \\
\hline LDL-cholesterol (mg/dL) - Altered & $158.90( \pm 22.60)$ & \\
\hline Cholesterol (mg/dL) - Altered & $147.03( \pm 14.10)$ & $<0.0001$ \\
\hline Cholesterol (mg/dL) - Normal & $210.50( \pm 30.39)$ & \\
\hline $\mathrm{HbA}_{1 \mathrm{c}}(\%)$ - Altered & $5.42( \pm 0.25)$ & $<0.0001$ \\
\hline $\mathrm{HbA}_{1 \mathrm{c}}(\%)$ - Normal & $6.68( \pm 1.64)$ & \\
\hline Insulin (uUI/mL) - Normal & $10.61( \pm 3.93)$ & $<0.0001$ \\
\hline Insulin (uUI/mL) - Altered & $33.15( \pm 14.51)$ & \\
\hline HOMA-IR - Normal & $2.49( \pm 0.78)$ & $<0.0001$ \\
\hline HOMA-IR - Altered & $7.80( \pm 6.30)$ & \\
\hline GMe (mg/dL) - Normal & $115.41( \pm 13.02)$ & $<0.0001$ \\
\hline GMe (mg/dL) - Altered & $163.79( \pm 53.61)$ & \\
\hline PAD (mmHg) - Normal & $6,83 \pm(1,29)$ & $<0.0001$ \\
\hline PAD (mmHg) - Altered & $7,9 \pm(1,19)$ & \\
\hline PAS (mmHg) - Normal & $11.61( \pm 1.50)$ & $<0.0001$ \\
\hline PAS (mmHg) - Altered & $14.85( \pm 1.02)$ & \\
\hline BMI $\left(\mathrm{kg} / \mathrm{m}^{2}\right)$ - Normal & $28.06( \pm 1.47)$ & $<0.0001$ \\
\hline BMI $\left(\mathrm{kg} / \mathrm{m}^{2}\right)$ - Altered & $39.59( \pm 5.28)$ & \\
\hline
\end{tabular}

Note: Data are expressed as means \pm SD or median (interquartile ranges); Data were processed for analysis Mann-Whitney; PAD: Diastolic Blood Pressure; BMI: Body Mass Index; GMe: Estimated Mean Glycemia; $\mathrm{HbA}_{1 c}$ : Glycated hemoglobin; T: T allele (band at 342 base pairs); C: C allele had two (216 base pairs and 126 base pairs).

Table 2 - Allelic frequencies of the polymorphism of the 5HT2A T102C gene, according to biochemical and anthropometric marker

\begin{tabular}{lllll}
\hline \multicolumn{1}{c}{ Parameters } & T & C & p value & ${ }^{\text {x2 value }}$ \\
\hline Triglycerides $(\mathrm{mg} / \mathrm{dL})$ - Normal & 50 & 50 & 1.000 & 0.00 \\
\hline Triglycerides $(\mathrm{mg} / \mathrm{dL})$ - Altered & 45 & 55 & 0.9203 & 0.04 \\
\hline HDL-cholesterol $(\mathrm{mg} / \mathrm{dL})$ - Normal & 45 & 55 & 0.3681 & 1.00 \\
\hline HDL-cholesterol $(\mathrm{mg} / \mathrm{dL})$ - Altered & 49 & 51 & 0.9203 & 0.04 \\
\hline LDL-cholesterol $(\mathrm{mg} / \mathrm{dL})$ - Normal & 45 & 55 & 0.3681 & 1.00 \\
\hline LDL-cholesterol $(\mathrm{mg} / \mathrm{dL})-$ Altered & 50 & 50 & 0.9203 & 0.18 \\
\hline Cholesterol $(\mathrm{mg} / \mathrm{dL})-$ Altered & 49 & 51 & 0.9203 & 0.04 \\
\hline Cholesterol $(\mathrm{mg} / \mathrm{dL})-$ Normal & 50 & 50 & 1.000 & 0.00 \\
\hline HbA ${ }_{1 \mathrm{c}}(\%)-$ Altered & 52 & 48 & 0.7642 & 0.16 \\
\hline
\end{tabular}




\begin{tabular}{|c|c|c|c|c|}
\hline Parameters & $T$ & C & $p$ value & $x^{2}$ value \\
\hline $\mathrm{HbA}_{1 \mathrm{c}}(\%)$ - Normal & 44 & 56 & 0.2713 & 1.44 \\
\hline Insulin (uUI/mL) - Normal & 46 & 54 & 0.4839 & 0.64 \\
\hline Insulin (uUI/mL) - Altered & 57 & 43 & 0.1936 & 1.96 \\
\hline HOMA-IR - Normal & 51 & 49 & 0.9203 & 0.04 \\
\hline HOMA-IR - Altered & 33 & 67 & $0.0010 *$ & 11.56 \\
\hline GMe (mg/dL) - Normal & 61 & 39 & $0.0270^{*}$ & 5.343 \\
\hline GMe (mg/dL) - Altered & 38 & 63 & $0.0228^{*}$ & 5.467 \\
\hline PAD (mmHg) - Normal & 45 & 55 & 0.3681 & 1.00 \\
\hline PAD (mmHg) - Altered & 24 & 76 & $<0.0001^{*}$ & 27.04 \\
\hline BMI $\left(\mathrm{kg} / \mathrm{m}^{2}\right)$ - Normal & 50 & 50 & 1.000 & 0.00 \\
\hline BMI $\left(\mathrm{kg} / \mathrm{m}^{2}\right)$ - Altered & 47 & 53 & 0.6171 & 0.36 \\
\hline
\end{tabular}

Note: The allele frequency distribution was expressed in\%. The data were analyzed by the chi-square test, being considered significant $\mathrm{p} \leq$ 0.05; PAD: Diastolic Blood Pressure; BMI: Body Mass Index; GMe: Estimated Mean Glycemia; $\mathrm{HbA}_{1 c}$ : Glycated hemoglobin; T: T allele (band at 342 base pairs); C: C allele had two (216 base pairs and 126 base pairs).

\section{DISCUSSION}

The $\mathrm{T} 102 \mathrm{C}$ polymorphism is related to the amount of $2 \mathrm{~A}$ receptors on the cell membrane in humans. It is known that the $C$ allele presents a $20 \%$ lower serotonin expression than the $\mathrm{T}$ allele. The results found suggest that a lower level of serotonin reflects on GMe, HOMA-IR and PAD. When related to allele frequencies and GMe, HOMAIR and PAD values reached significant differences, confirming its association with the $C$ allele. Low levels of serotonin or problems in signaling with its receptor have been related to an increase in the desire for higher carbohydrate intake ${ }^{16}$ among several species, under various experimental conditions. There is strong evidence that the increase in the postsynaptic activity of the serotonergic receptors subsequently causes reduction in amount of food eaten during a meal and modifies the feeding pattern. ${ }^{1718}$ Thus, knowing that HOMAIR and GMe are related to glucose homeostasis, the association of the altered dosages of these markers to the $C$ allele is possibly a reflection of the higher caloric intake and lower satiety due to the lower serotonin reuptake. ${ }^{16}$ The lack of measurement of habitual energy intake (diet record), was not carried out in this study and representes a important limitation, but that does not detract from the presented data.

Other pharmacological and genetic studies have also shown direct effects of 5-HT2C on glucose homeostasis. Bechtholt, Smith, Gaughan and Lucki ${ }^{3}$ reported the role 
of the $5-\mathrm{HT} 2 \mathrm{C}$ receptor on glucose homeostasis in rodents. The rats treated with serotonin reuptake inhibitors showed an improvement in glucose tolerance and the interaction between serotonin and leptin in glucose homeostasis makes the serotonergic system a possible target for the treatment of diabetes and obesity. ${ }^{19}$ Ward, Jackson, Lefever and Tallarida ${ }^{20}$ and Wade, Juneja, MacKay, Graham, Havel, Tecott, et al. ${ }^{21}$ found that rats without the serotonergic (5-HT) receptor became hyperphagic and obese. In humans, 5-HT indirect agonist (fenfluramine and dexfenfluramine) has been used for a few years to treat obesity by producing significant weight loss and sustained decrease in appetite.

In a study, dexfenfluramine was administered to rats with free access to food. Following the administration of the substance, there was a drastic reduction in food consumption, especially those containing sugar. In this study, we can highlight that the higher concentration of serotonin is associated with a marked decrease in sugar consumption, whereas in our study, individuals with the allele (C) associated with lower serotonin expression presented an imbalance in glucose homeostasis, suggesting that these appear to have higher sugar consumption. ${ }^{22}$ Other studies related the $\mathrm{T}^{2} \mathrm{O} 2 \mathrm{C}$ polymorphism of the $5-\mathrm{HT} 2 \mathrm{~A}$ gene to the prevalence of cardiovascular diseases, acute myocardial infarction and cholesterolemia. ${ }^{23,24}$

In a study using animal model, Lopez-Esparza, Berumen, Padilla, Miledi and García-Alcocer ${ }^{25}$ demonstrated modifications in the expression of the 5-HT 2A and 5HT $2 \mathrm{C}$ alleles in the hippocampus of mice with diet-induced obesity supplemented with tryptophan, suggesting that the hypercaloric diet causes reduction in receptor expression, contributing to the development and progression of obesity. Spadaro, Naug, Du Toit, Donner, Colson ${ }^{26}$ found significant differences in the allelic frequencies of the $5 \mathrm{HT} 2 \mathrm{~A}$ gene between a control population and an obese population in Poland, suggesting a correlation between polymorphism and obesity. In a neuropsychological and behavioral study, they demonstrated that agonism of $5 \mathrm{HT} 2 \mathrm{~A}$ receptors is related to satiety and reduction of food intake. Allelic frequencies of the 5-HT2A genotype presented significant differences between the control and obese population, suggesting the relation between the expression of the receptor and the prevalence of the disease. ${ }^{27}$

Drugs that inhibit the reuptake of 5-HT neurotransmitters, allowing them to remain in greater amounts and for a longer time in the synaptic cleft, promote a greater sensation of satiety and, in experimental studies, demonstrate an increase in basal metabolism. ${ }^{10}$ Serotoninergic circuits have been used for some time as an excellent target for the design 
of drugs to treat obesity. Drugs such as dexfenfluramine act to block the reuptake of serotonin in post-synaptic terminals of the serotonergic circuits, promoting the sensation of satiety and reducing the craving for carbohydrates and fats in detriment of protein intake. However, the role of the genes encoding serotonin receptors in the pathogenesis of obesity has not yet been fully elucidated..$^{28,29}$

Thus, the data presented here corroborate with other studies that demonstrated the relationship of the $\mathrm{T} 102 \mathrm{C}$ polymorphism of the $5 \mathrm{HT} 2 \mathrm{~A}$ gene to the regulation of appetite and energy homeostasis. ${ }^{29}$ Thus, we also highlight the important role of the brain and central nervous system on eating behavior and on the influence on hypertension. . $^{13,19}$

\section{CONCLUSION}

From the genotypic analyzes of the T102C polymorphism of the 5HT2A gene, it was possible to demonstrate a relationship between the presence of the $C$ allele with biochemical and anthropometric markers related to obesity and hypertension. These results corroborate the use of the regulation of serotonergic circuits in the control of food intake, serving as a subsidy for strategies to prevent hypertension and obesity.

\section{CONFLICTS OF INTEREST}

There are no conflicts of interest.

\section{ACINOWLEDGEMENTS}

The authors thank the University of Western Santa Catarina (Unoesc), Brazil, for their support in this study. In addition, we would like to thank all the volunteers who participated in this study, especially the Groups of Indians Athletes of São Miguel do Oeste, SC. 


\section{REFERENCES}

1. Bickerdike MJ. 5-HT 2C Receptor Agonists as Potential Drugs for the Treatment of Obesity. Current. 2003;885-97, 2003.

2. World Health Organization. Obesity: preventing and managing the global epidemic Report of a WHO Consultation (WHO Technical Report Series 894). 2000.

3. Bechtholt AJ, Smith K, Gaughan S, Lucki I. Sucrose intake and fasting glucose levels in 5-HT 1A and 5-HT 1B receptor mutant mice. Physiology \& behavior. 2008;93:659-65.

4. Voigt JP, Fink $\mathrm{H}$. Serotonin controlling feeding and satiety. Behavioural Brain Research. 2015;277:14-31.

5. Feijó FDM, Bertoluci MC, Reis C. Serotonina e controle hipotalâmico da fome: uma revisão. Rev. Assoc. Med. Bras. 2011;57(51):74-77.

6. Naves A, Paschoal VCP. Regulação funcional da obesidade. ConScientiae Saúde. 2007;6(1):189-99.

7. Lam DD, Przydzial MJ, Ridley SH, Yeo GS, Rochford JJ, O'Rahilly S, et al. Serotonin $5-\mathrm{HT} 2 \mathrm{C}$ receptor agonist promotes hypophagia via downstream activation of melanocortin 4 receptors. Endocrinology. 2008;149(3):1323-28.

8. Rossi L, Tirapegui J. Implicações do sistema serotoninérgico no exercício físico. Arq Bras Endocrinol Metab. 2004;48(2):227-33.

9. Yuan X, Yamada K, Ishiyama-Shigemoto S, Koyama W, Nonaka K. Identification of polymorphic loci in the promoter region of the serotonin $5-\mathrm{HT} 2 \mathrm{C}$ receptor gene and their association with obesity and type II diabetes. Diabetologia. 2000;43(3):373-6.

10. Polesskaya OO, Sokolov BP. Differential expression of the " $C$ " and " $T$ " alleles of the $5-\mathrm{HT} 2 \mathrm{~A}$ receptor gene in the temporal cortex of normal individuals and schizophrenics. J. Neurosci. Res. 2002;67(6):812-22.

11. Mistry KG, Gohil PV. 5-HT2A receptor: A newertarget for Obesity. Int. J. Pharmtech Res. 2011;3(4):2089-95, 2011. 
12. World Health Organization. Obesity: preventing and managing the global epidemic. Report of a World Health Organization Consultation. World Health Organ Tech Rep Ser. 2000;894(1-12):1-253.

13. Friedewald WT, Levy RI, Fredrickson DS. Estimation of the concentration of low-density lipoprotein cholesterol in plasma, without use of the preparative ultracentrifuge. Clin. Chem. 1972;18(6):499-502.

14. Katz A, Nambi SS, Mather K, Baron AD, Follmann DA, Sullivan G, et al. Quantitative insulin sensitivity check inex: a simple, accurate method for assessing insulin sensitivity in humans. J Clin Endocrinol Metab. 2000;85(7):2402-10.

15. Weiner JS, Lourie JA. Practical Human Biology. London: Academic Press; 1981. p. 439.

16. Matsuda JB et al. Polimorfismos dos genes do receptor de serotonina (5-HT2A) e da catecol-O-metiltransferase (COMT): fatores desencadeantes da fibromialgia? ver Bras Reumatol. 2010;50(2):141-45.

17. Khait VD, Huang YY, Zalsman G, Oquendo MA, Brent DA, Harkavy-Friedman JM, et al. Association of serotonin 5-HT2A receptor binding and the $\mathrm{T} 1 \mathrm{O} 2 \mathrm{C}$ polymorphism in depressed and healthy Caucasian subjects. Neuropsychopharmacology: official publication of the American College of Neuropsychopharmacology. 2005;30(1):166-72.

18. Montero LF, De Castro QL. Obesidade: Controle Neural e Hormonal do Comportamento Alimentar Obesity: Neuro-hormonal controloffoodintake. Med. Biol. 2011;103:236-45.

19. Ferreira L, Gomes E. Estudo sobre a eficácia do uso de inibidores da recaptação de norepinefrina e serotonina no tratamento da obesidade (Sibutramina ${ }^{\circledR}$ ). Rev. Saúde e Pesq. 2009;2(3):363-69.

20. Ward SJ, Jackson C, Lefever TW, Tallarida RJ. Effects of a Cannabinoid 1 Receptor Antagonist and Serotonin 2C Receptor Agonist Alone and in Combination on Motivation for Palatable Food: A Dose-Addition Analysis Study in Mice. J Pharmacol Exp Ther. 2008;325(2):567-76.

21. Wade JM, Juneja P, MacKay AW, Graham J, Havel PJ, Tecott LH, et al. Synergistic impairment of glucose homeostasis in ob/ob mice lacking functional serotonin $2 \mathrm{C}$ receptors. Endocrinology. 2008;149(3):955-61. 
22. Rowland NE, Mukherjee M, Robertson K. Effects of the cannabinoid receptor antagonist SR 141716, alone and in combination with dexfenfluramine or naloxone, on food intake in rats. Psychopharmacology. 2002;159(1):111-16.

23. Sanders-Bush E, Fentress H, Hazelwood L. Serotonin 5-ht2 receptors: molecular and genomic diversity. Mol. Interv. 2003;3(6):319-30.

24. Yamada S, Akita H, Kanazawa K, Ishida T, Hirata K, Ito K, et al. T1O2C polymorphism of the serotonin (5-HT) $2 \mathrm{~A}$ receptor gene in patients with non-fatal acute myocardial infarction. Atherosclerosis. 2000;150(1)143-8.

25. Lopez-Esparza S, Berumen LC, Padilla K, Miledi R, García-Alcocer G. Expression of hippocampal serotonin receptors $5-\mathrm{HT} 2 \mathrm{C}$ and $5-\mathrm{HT} 5 \mathrm{~A}$ in a rat model of diet-induced obesity supplemented with tryptophan. Int J Dev Neurosci. 2015;42:80-85.

26. Spadaro PA, Naug HL, Du Toit EF, Donner D, Colson NJ. A refined high carbohydrate diet is associated with changes in the serotonin pathway and visceral obesity. Genet. Res. 2015;97:23.

27. Weber ET, Andrade R. Htr2a gene and 5-HT2A receptor expression in the cerebral cortex studied using genetically modified mice. Front Neurosci. 2010;4:1-12.

28. Marston OJ, Heisler LK. Targeting the serotonin $2 \mathrm{C}$ receptor for the treatment of obesity and type 2 diabetes. Neuropsychopharmacology: official publication of the American College of Neuropsychopharmacology. 2009;34(1):252-53.

29. Yamamoto $M$. et al. Interaction between serotonin $2 A$ receptor and endothelin-1 variants in association with hypertension in Japanese. Hypertension research: official journal of the Japanese Society of Hypertension. 2006;29(4):227-32.

Recebido em: 22 de abril de 2019 Avaliado em: 13 de maio de 2019 (Avaliador A) Avaliado em: 14 de junho de 2019 (Avaliador B) Aceito em: 29 de setembro de 2019 
